\title{
Atlantic puffin Fratercula arctica and common guillemot Uria aalge chick diet and growth as indicators of fish stocks in the Barents Sea
}

\author{
Robert T. Barrett* \\ Department of Zoology, Tromsø University Museum, 9037 Tromsø, Norway
}

\begin{abstract}
Between 1980 and 2000, Atlantic puffins Fratercula arctica and common guillemots Uria aalge breeding in the southern Barents Sea fed their chicks on varying proportions of 4 main categories of prey: capelin Mallotus villosus, sandeels Ammodytes sp., I-group herring Clupea harengus and 0-group cod Gadus morhua. The varying proportions in both numbers and masses of the capelin, herring and cod in the seabird diet showed clear responses to the independently measured prey stocks. Amounts of capelin, herring and 0-group cod fed to Atlantic puffin chicks were good indicators of fish availability, whereas only amounts of herring fed to common guillemot chicks were correlated with the biomass of I-group herring in the region. The more general response by the Atlantic puffins probably results from their ability to catch only small fishes. Despite large interannual differences in prey consumption plus gradual changes in meal sizes, the growth rates of the chicks of both species remained near their maximum, suggesting physiological restraints in growth during plentiful years and/or compensatory foraging behaviour by the adults.
\end{abstract}

KEY WORDS: Atlantic puffins - Common guillemots - Chick diet - Chick growth · Fish stocks · Bioindicators · Barents Sea

\section{INTRODUCTION}

The choice of food by seabirds is often a good shortterm indicator of prey availability and hence oceanographic and/or anthropogenic influences on the marine environment (see review by Montevecchi 1993). As a result, long-term studies of seabird feeding ecology can be useful in understanding trophic relationships within a given region, and can provide data on the abundance of prey not normally sampled by conventional fisheries research methods (Montevecchi et al. 1988, Barrett 1991, Cairns 1992, Montevecchi \& Myers 1995).

The Barents Sea (Fig. 1) is small $\left(1.4 \times 10^{6} \mathrm{~km}^{2}\right)$ and, being a polar sea, has a relatively simple ecosystem with few key species at each trophic level. Its simplic-

*E-mail: robb@imv.uit.no ity results in an extremely dynamic situation and pronounced variations in the oceanographic climate have had significant influences on the trophic ecology of the sea (Sakshaug et al. 1994, Sakshaug 1997).

In recent years, environmental perturbations such as commercial (over)exploitation of some key fish species have caused major (i.e. in orders of magnitude) stock fluctuations resulting in dramatic responses by some top predators. For instance, in the late 1980s, hundreds of thousands of harp seals Phoca groenlandica underwent unusual winter migrations to and along the coast of Norway, while at several seabird colonies in the SW Barents Sea, numbers of breeding common guillemots Uria aalge collapsed by 70 to $90 \%$ (Vader et al. 1990, Haug et al. 1991). Both these episodes were a response to the near absence of Norwegian spring-spawning herring Clupea harengus in the Barents Sea and the collapse of the Barents Sea capelin Mallotus villosus stock from ca. 4 million tonnes in 1983 to 0.1 million 


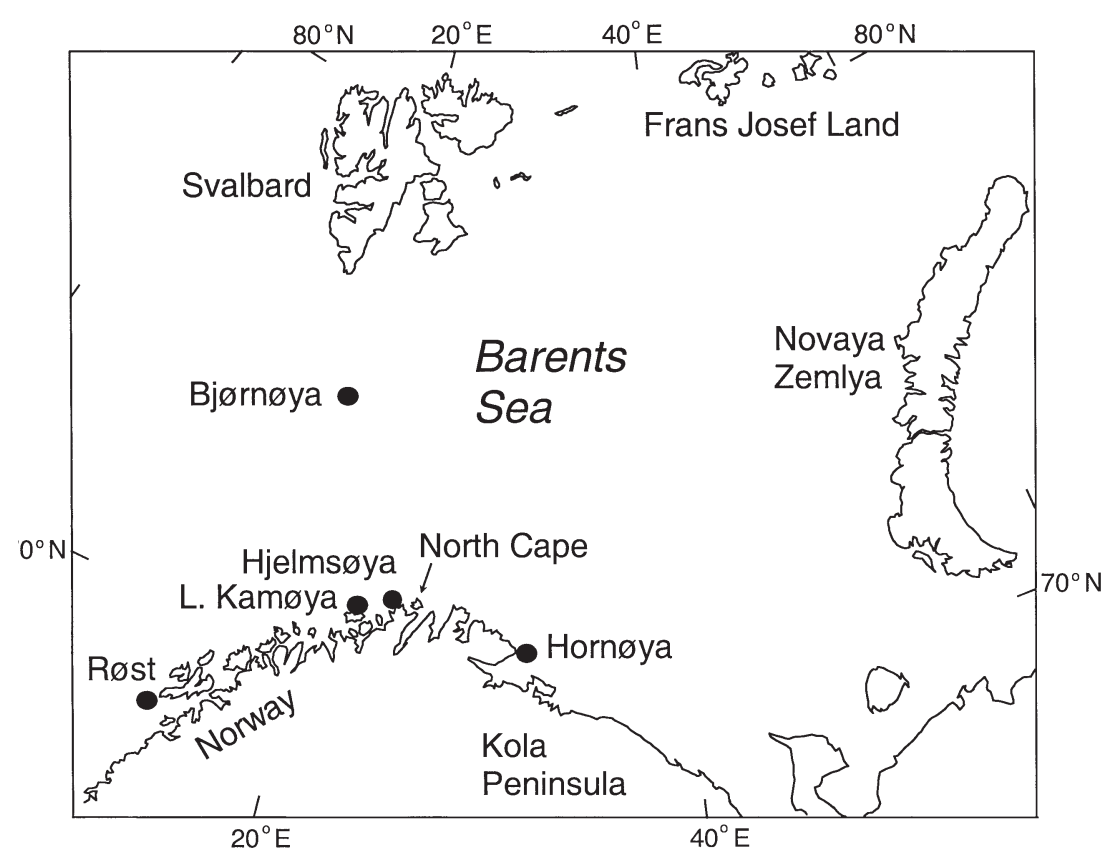

Fig. 1. Barents Sea and positions of localities referred to in text pairs breed on Svalbard, a few hundred on Novaya Zemlya, and none on Frans Josef Land (Anker-Nilssen \& Tatarinkova 2000).

Common guillemots are less numerous, and numbers breeding on the mainland coast have dropped greatly from $>150000$ pairs when the first counts were made in the 1960 s to 10000 to 15000 pairs today. Much of this drop has been attributed to bycatches of adults in fishing gear (Brun 1979, Strann et al. 1991, Barrett \& Golovkin 2000). Today ca. 130000 to 150000 pairs breed in Norway and Svalbard, with the majority (10 000 pairs) on Bjørnøya (Bakken unpubl. data in Barrett \& Golovkin 2000).

Atlantic puffins and common guillemots catch their prey within a few tens of kilometres from the coast by pursuitdiving at depths of 10 to $40 \mathrm{~m}$ and 20 to $180 \mathrm{~m}$ respectively (Bradstreet \& Brown 1985, Piatt \& Nettleship 1985, Burger \& Simpson 1986, Barrett \& Furness 1990). Food brought to the chicks is almost entirely small fishes that are held in the bill and easily observed, identified or collected. In Norway, Atlantic puffins generally harvest small fish, ca. 30 to $80 \mathrm{~mm}$ in length, but some clupeids or sandeels Ammodytes sp. up to ca. $170 \mathrm{~mm}$ have been recorded (Barrett et al. 1987). Fish caught by common guillemots are generally larger (100 to $150 \mathrm{~mm}$ : Barrett \& Furness 1990, Barrett et al. 1997a). Although a wide variety of species caught by both species has been identified, the commonest in Norway are small pelagic species such as sandeels, capelin and I-group herring, or the youngest, pelagic stages of demersal fish such as cod Gadus morhua, saithe Pollachius virens and haddock Melanogrammus aeglefinus (Anker-Nilssen 1987, Barrett et al. 1987, 1997b).

Since 1979, the breeding populations of Atlantic puffins and common guillemots have been monitored at 4 large colonies spread along the Norwegian coast (Runde [in SW Norway], Røst, Hjelmsøya and Hornøya [present Fig. 1]: Anker-Nilssen et al. 1996). While the main emphasis of the study has been on counts of breeding populations, it was also recognized that any changes in their numbers are poor monitors of environmental change due to the buffering effect of their low fecundity rate and late maturity of both species. More useful information can be gained from studies of behaviour and reproduction, e.g. food choice, chick growth and reproductive success, which all respond much more rapidly to changes in food availability (Cairns 1987, Montevecchi 1993). As a result, addi- 
tional details of various breeding parameters have been collected annually at Røst (Anker-Nilssen \& Brøseth 1998) and Hornøya (Barrett \& Krasnov 1996) in order to identify any responses by seabirds to changes in the marine ecosystem.

This paper addresses the studies of the Atlantic puffin and common guillemot at Hornøya, eastern Finnmark $\left(72^{\circ} 22^{\prime} \mathrm{N}, 31^{\circ} 10^{\prime} \mathrm{E}\right)$. Because this site is near the northeastern limit of the North Atlantic distribution range of both species (Gaston \& Jones 1998, AnkerNilssen et al. 2000), any small changes in oceanographic conditions and food availability can be expected to result in large responses by both species. However, because Atlantic puffins (ca. 450 to $500 \mathrm{~g}$ ) are smaller than common guillemots (1000 to $1100 \mathrm{~g}$ ) and more restricted in the depths and duration of their dives, foraging ranges and size of fishes caught, and thus in their ability to compensate for adverse conditions, a more marked response by the Atlantic puffins is expected. Such responses would, in the short term, probably manifest themselves in changes in the species composition and the amount of fish caught (Montevecchi et al. 1988, Martin 1989, Nettleship 1991) and, in cases of serious food shortages, in chick growth rates (Cairns 1992). Data on prey harvest, the sizes and amounts of fishes fed to chicks and chick growth are presented.

\section{METHODS}

In 1980 to 1982, Atlantic puffin chick food was sampled by the retrieval of items carried by adults caught in mist nets. Common guillemot chick food was sampled by collecting fish discarded on the breeding ledges. All items were counted, weighed $( \pm 0.05 \mathrm{~g})$ and measured (total length $\pm 0.5 \mathrm{~mm}$ ). To reduce disturbance and to increase sample sizes, chick food data were collected in subsequent years by direct observation (using $10 \times 40$ binoculars) of food items carried by adults of both species into the colony. Where possible, all food items were identified to species and counted, and the proportions of each taxon were estimated by mass. To determine the mass of items carried by Atlantic puffins, their sizes were first estimated as multiples of the straight bill length of the adult (ca. $30 \mathrm{~mm}$ : Barrett et al. 1985). Those of common guillemots were categorized as small, medium, large and very large, again in relation to bill length (Barrett et al. 1997a). To check identification and length estimates, control samples were collected from adults caught using a noosepole. The masses of individual items not collected were then integrated from estimated lengths based on length/mass relationships determined from the control samples.
Although 2 methods were used to assess puffin diet (collection of samples dropped by mist-netted adults in 1980 to 1982 and direct observations during the subsequent years), Rodway \& Montevecchi (1996) showed that only slight correction factors were necessary to make the 2 methods comparable. They considered direct observations to be 'reliable' and to have the advantage over mist-netting that numbers of larval fish were more likely to be detected and it was less disturbing to the birds. In this study, however, the identification of small larvae by direct observation was very difficult (e.g. when trying to separate larval capelin, sandeels and herring), as was the estimation of numbers of larvae. There was thus always the need to collect control samples.

To determine puffin chick growth in 1980 and 1981, ca. 40 to 50 marked nests were inspected once every 1 to $3 \mathrm{~d}$ during the late incubation and throughout the chick-rearing periods (Barrett 1984, Barrett et al. 1987). To reduce any impact of disturbance on breeding success, nests were checked once only during the incubation period and twice only during chick-rearing at about 10 to $20 \mathrm{~d}$ intervals in 1988 and thereafter. To avoid possible inter-annual variations in growth due to changes in e.g. nest density, aspect, slope or distance from cliff edge (Harris 1980, Rodway et al. 1998), the same nests or, when abandoned, neighbouring nests were used each year. Being spread across the whole island, the total sample was considered representative of the colony.

All puffin chicks were weighed $( \pm 2.5 \mathrm{~g})$ and their wings were measured (maximum flattened chord, including down but minus the little tuft at the end; $\pm 2.5 \mathrm{~mm}$ when downy; and $\pm 0.5 \mathrm{~mm}$ after the eruption of the feathers). In 1988 and subsequent years, chick growth rates ( $\mathrm{g}$ or $\mathrm{mm} \mathrm{d}^{-1}$ ) were estimated by simply dividing the change in chick body mass or wing length by the interval between the 2 measurements. These estimates were restricted to measurements made in the linear phase of growth by omitting from the analysis very early-hatched chicks whose growth curves had obviously reached the asymptote in the days between the 2 visits. For 1980 and 1981, measurements from 2 arbitrary days $15 \mathrm{~d}$ apart within the chick-rearing period were used in the same manner.

Common guillemot chicks were either noose-poled on the colony towards the end of the chick-rearing period, or caught under the cliffs as they departed from the colony. They were also weighed $( \pm 2.5 \mathrm{~g})$ and their wings measured $( \pm 0.5 \mathrm{~mm})$. Because there is little change in the mass of the chick once the wing length has reached 60 to $70 \mathrm{~mm}$ (Harris \& Wanless 1988, Barrett et al. 1997a), the mean mass of chicks with wings $\geq 70 \mathrm{~mm}$ was taken as an index of fledging condition. 
Table 1. Fratercula arctica. Protocol of sampling and percentage by numbers (n) and by mass of prey items brought to Atlantic puffin chicks at Hornøya, north Norway, 1980 to 2000. Data for 1980 to 1982 are based on collected samples, for 1983 to 2000 mainly on items observed being carried by adult birds. nd: no data available; tr: trace $(<0$ to $0.5 \%)$. Prey items were the capelin Mallotus villosus, the sandeel Ammodytes sp., the herring Clupea harengus, gadids (the cod Gadus morhua), the wolffish Anarhichas lupus, and 'other'

\begin{tabular}{|c|c|c|c|c|c|c|c|c|c|c|c|c|c|c|c|c|c|}
\hline \multirow[t]{2}{*}{ Year } & \multirow{2}{*}{$\begin{array}{l}\text { Mean } \\
\text { hatch } \\
\text { date }^{a}\end{array}$} & \multirow{2}{*}{$\begin{array}{c}\text { Main } \\
\text { sampling } \\
\text { dates }(\mathrm{d} / \mathrm{mo})\end{array}$} & \multicolumn{2}{|c|}{$\begin{array}{c}\text { No. of } \\
\text { loads items }\end{array}$} & \multirow{2}{*}{$\begin{array}{l}\text { Total } \\
\text { mass } \\
(g)\end{array}$} & \multicolumn{2}{|c|}{$\begin{array}{c}\text { Capelin } \\
\%\end{array}$} & \multicolumn{2}{|c|}{$\begin{array}{l}\text { Sandeel } \\
\%\end{array}$} & \multicolumn{2}{|c|}{$\begin{array}{l}\text { Herring } \\
\%\end{array}$} & \multicolumn{2}{|c|}{$\begin{array}{l}\text { Gadids } \\
\%\end{array}$} & \multicolumn{2}{|c|}{$\begin{array}{l}\text { Wolf- } \\
\text { fish \% }\end{array}$} & \multicolumn{2}{|c|}{$\begin{array}{l}\text { Other } \\
\%\end{array}$} \\
\hline & & & & & & $\mathrm{n}$ & mass & $\mathrm{n}$ & mass & $\mathrm{n}$ & mass & $\mathrm{n}$ & mass & $\mathrm{n}$ & mass & $\mathrm{n}^{\mathrm{b}}$ & mass \\
\hline 1980 & 30 June & $3 / 7-2 / 8$ & 72 & 212 & 740 & 69 & 76 & 20 & 21 & 0 & 0 & 0 & 0 & 3 & 1 & 8 & 2 \\
\hline 1981 & 8 July & $7 / 7-16 / 8$ & 52 & 119 & 535 & 38 & 37 & 62 & 63 & 0 & 0 & 0 & 0 & 0 & 0 & 0 & 0 \\
\hline 1982 & 29 June & $1-25 / 7$ & 49 & 113 & 511 & 66 & 74 & 31 & 26 & 0 & 0 & 2 & $\operatorname{tr}$ & 1 & $\operatorname{tr}$ & 0 & 0 \\
\hline 1983 & nd & $28 / 6-20 / 7$ & 193 & 242 & 274 & 19 & 27 & 61 & 68 & 0 & 0 & 0 & 0 & 0 & 0 & 21 & 5 \\
\hline 1987 & nd & $15-17 / 7$ & 19 & 53 & 121 & 25 & 25 & 51 & 67 & 0 & 0 & 0 & 0 & 19 & 8 & 6 & 0 \\
\hline 1989 & 21 June & $6-12 / 7$ & 15 & 79 & 120 & 18 & 73 & 34 & 1 & 0 & 0 & 37 & 15 & 5 & 4 & 6 & 7 \\
\hline 1990 & 27 June & $2-28 / 7$ & 151 & 380 & 1069 & 16 & 46 & 48 & 47 & 1 & 5 & 9 & 2 & 0 & 0 & 26 & $\operatorname{tr}$ \\
\hline 1991 & 28 June & $21 / 6-11 / 7$ & 35 & 90 & 168 & 18 & 30 & 53 & 64 & 0 & 0 & 18 & 5 & 0 & 0 & 11 & 1 \\
\hline 1992 & 29 June & $5-15 / 7$ & 80 & 286 & 898 & 12 & 20 & 8 & 26 & 6 & 29 & 66 & 25 & 1 & $\operatorname{tr}$ & 0 & 0 \\
\hline 1993 & 1 July & $28 / 6-28 / 7$ & 221 & 1264 & 1022 & 61 & 39 & 33 & 19 & 4 & 41 & 1 & $\operatorname{tr}$ & $\operatorname{tr}$ & 1 & $\operatorname{tr}$ & $\operatorname{tr}$ \\
\hline 1994 & 28 June & $29 / 6-9 / 8$ & 229 & 1171 & 1617 & 5 & 25 & 16 & 42 & 1 & 3 & 32 & 13 & 12 & 15 & 33 & 3 \\
\hline 1995 & 2 July & $28 / 6-29 / 7$ & 420 & 2666 & 3502 & 3 & 16 & 8 & 30 & 8 & 7 & 62 & 33 & 7 & 12 & 11 & 2 \\
\hline 1996 & 29 June & $3-22 / 7$ & 164 & 1349 & 1235 & 2 & 14 & 10 & 35 & $\operatorname{tr}$ & $\operatorname{tr}$ & 85 & 49 & 1 & 2 & 1 & 1 \\
\hline 1997 & 5 July & $13-22 / 7$ & 107 & 665 & 573 & 14 & 30 & 12 & 35 & 1 & 7 & 62 & 22 & 3 & 5 & 8 & 1 \\
\hline 1998 & 30 June & $13-21 / 7$ & 164 & 1963 & 1250 & 1 & 23 & $\operatorname{tr}$ & 7 & $\operatorname{tr}$ & 4 & 19 & 14 & $\operatorname{tr}$ & $\operatorname{tr}$ & 57 & 52 \\
\hline 1999 & 29 June & $6-22 / 7$ & 171 & 530 & 950 & 3 & 13 & 27 & 58 & 4 & 18 & 66 & 10 & 0 & 0 & 0 & 0 \\
\hline 2000 & 2 July & $8-20 / 7$ & 141 & 1285 & 964 & 4 & 26 & 5 & 22 & 0 & 0 & 86 & 47 & 0 & 0 & 6 & 5 \\
\hline
\end{tabular}

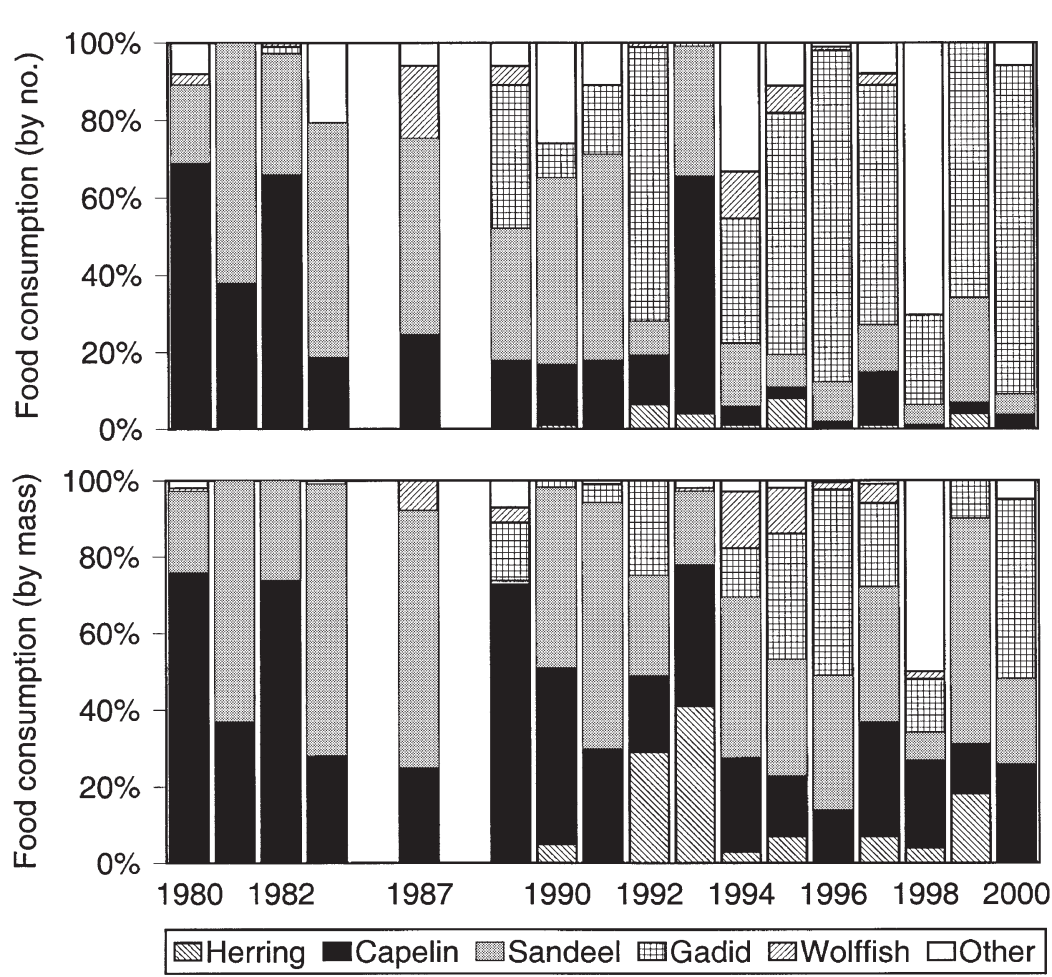

Fig. 2. Fratercula arctica. Composition of Atlantic puffin chick diet (\% by number and \% by mass) at Hornøya. Sample sizes and specific names of prey are given in Table 1
Independent annual estimates of fish stock sizes in the Barents Sea were taken from ICES Working Group Reports (Anonymous 2000, 2001) and Toresen (2000). All statistical tests were carried out using Minitab Release 12, and all percentage data were arcsinetransformed before being entered into regression equations.

\section{RESULTS}

\section{Atlantic puffin}

A total of 2283 Atlantic puffin food loads were either collected or observed in 17 seasons between 1980 and 2000 . Nearly 12500 food items were identified, and weighed an estimated $14.8 \mathrm{~kg}$ (Table 1). With the exception of 1987 and 1989, when few $(<20)$ samples were collected, and 1991 when all samples were collected very early in the season (with $75 \%$ on 3 and 4 July), all samples were collected during the first 2-thirds of the chick-rearing period when chick growth is rapid (Table 1). 
Of the sample periods, 5 were of $2 \mathrm{wk}, 2$ of $3 \mathrm{wk}$ and 7 of 4 wk or more (Table 1). Although the shorter periods may have missed any seasonal variations in diet, as found further south in Norway (Anker-Nilssen 1987, Barrett et al. 1987), little variation was detected at Hornøya during the first 3 yr (Barrett et al. 1987). With the exception of the data for the 3 shortest seasons (1987, 1989, 1991), which are excluded from statistical analyses, the data from the other years are considered representative for the seasons in question.

Between 1990 and 2000, 50 control samples were collected after bill-load contents had been identified by direct observation and the sizes and hence masses of the individual fish estimated. The estimated load masses were on average $102 \pm 40 \%$ of the measured load masses. Although the margin of error in the estimates of load mass was large, the results of the 2 sampling methods are considered directly comparable.

There were 6 main prey categories in chick diets: capelin, sandeels, herring, gadids, wolffish Anarhichas lupus, and 'other'. When sampled, the gadids were identified as 0-group cod. There were considerable inter-annual changes in diet composition (Table 1, Fig. 2). In 1980 and 1982 (and possibly 1989), > 70\% by mass of the food was capelin, whereas in 1981, 1983 (and possibly 1987, 1991) and $1999>50 \%$ were sandeels. The mean lengths of the capelin ranged from ca. 65 to $125 \mathrm{~mm}$ (equivalent to I- to II-group) and those of sandeels between 70 and $115 \mathrm{~mm}$. Included in the samples was a sandeel caught in 1980, which was $157 \mathrm{~mm}$ long and weighed $16.6 \mathrm{~g}$. Herring was absent in the early 1980 s but constituted $>10 \%$ of the diet in 1992, 1993 and 1999. With the exception of a few 0group fish caught in 1992, all herring were I-group fish with a mean length of $102.6 \pm 23.7 \mathrm{~mm}$ ( $\mathrm{n}=118 \mathrm{fish})$. 0 group (35 to $50 \mathrm{~mm}$ ) gadids made up $10 \%$ or more by mass of the diet in (1989), 1992 and 1994 to 2000. In 1994 and 1995, 50 to $70 \mathrm{~mm}$ fry of wolffish made up 15 and $12 \%$ of the diet respectively. Included in the category 'other' were 60 to $70 \mathrm{~mm}$ spotted snake blenny (or daubed shanny) Leptoclinus maculatus that in 1998 made up $50 \%$ of the total mass of fishes delivered to the chicks.

Among the prey taxa, only 2 significant time trends were found: those of 0 -group gadid and capelin. The contribution of the former increased between 1980 and $2000\left(y=-33.9+1.7 x, r^{2}=44.3, p=0.009, d f=12\right)$ while the latter decreased $\left(y=48.2-0.2 .4 x, r^{2}=53.4\right.$, $\mathrm{p}=0.002$, $\mathrm{df}=12$ ). The mean number of fishes per load and the mean load mass varied significantly among years $\left(F_{12,1977}=36.4, \mathrm{p}=0.000 ;\right.$ and $F_{12,1723}=24.9, \mathrm{p}=$ 0.000 respectively). The mean number per load increased significantly between 1980 and 2000 (Fig. 3A, $\mathrm{r}^{2}=46,2, \mathrm{p}=0.007, \mathrm{df}=12$ ) while the load mass decreased in the same period (Fig. 3B, $\mathrm{r}^{2}=58.5 \%, \mathrm{p}=$
0.001, df = 12). The heaviest load sampled (on 15 July 1982) weighed $33 \mathrm{~g}$ and consisted of 6 capelin weighing 4.5 to $6.5 \mathrm{~g}$ each.

The number of fishes in each load increased with the relative mass of 0 -group gadids in the diet $(y=$ $\left.4.1+8.3 x, r^{2}=31.5 \%, p=0.046, d f=11\right)$. The maximum mean number of fishes per load (11.8) was, however, attained in 1998 when the snake blenny made up $50 \%$ of the diet. Numbers of fishes per load decreased with increasing amounts (by mass) of sandeels $\left(y=8.7-9.5 x, r^{2}=37.5 \%, p=0.026\right.$, df $\left.=11\right)$ and with increasing amounts of sandeels + capelin $\left(y=12.0-7.4\right.$ [capelin]-11.4[sandeels], $\mathrm{r}^{2}=79.8, \mathrm{p}=$ 0.000 , df $=10$ ). Similarly there was a positive correlation between the load mass and the amount of capelin in the diet $\left(y=5.9+5.8 x, r^{2}=35.8, p=0.031\right.$, df $\left.=11\right)$, and a tendency for the opposite with respect to gadid fry. The proportion of gadid fry in the diet increased as that of capelin decreased $\left(y=0.3-0.44 x, r^{2}=31.6\right.$, $\mathrm{p}=0.037, \mathrm{df}=12$ ). No other relationships between prey diets were found.

Chick mass-increment rates varied significantly $\left(F_{15,395}=3.23, \mathrm{p}=0.000\right)$ between 9.1 and $13.3 \mathrm{~g} \mathrm{~d}^{-1}$,
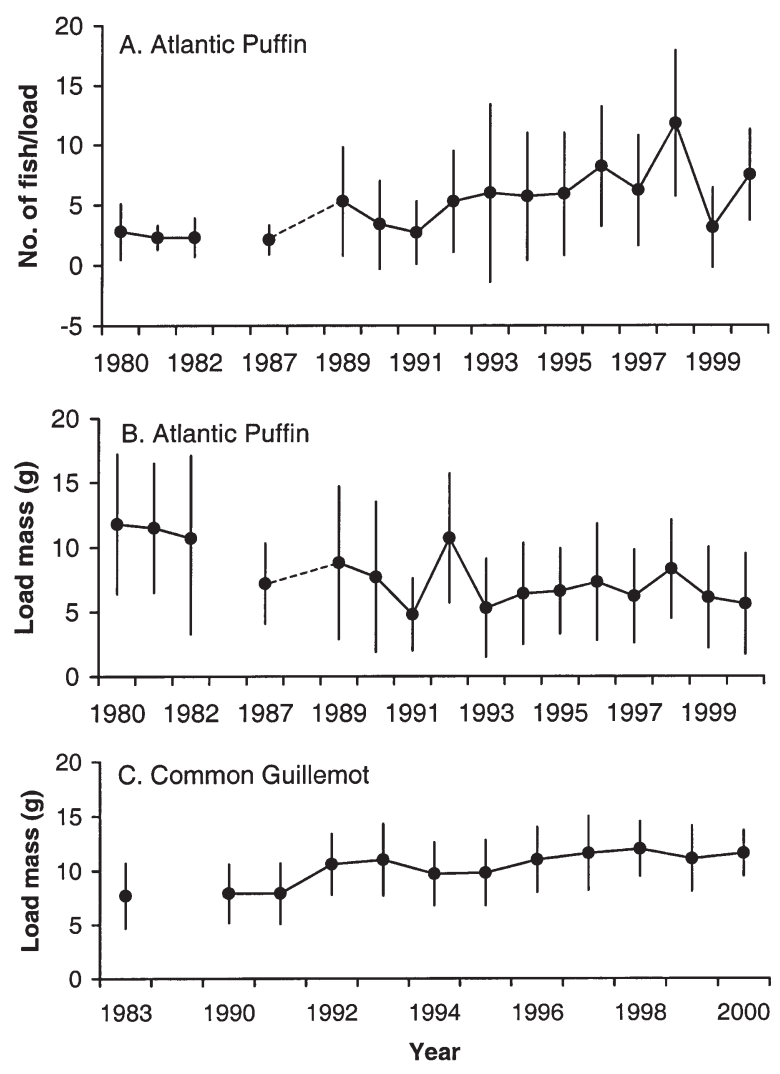

Fig. 3. Fratercula arctica and Uria aalge. (A) Mean number of fishes per beak load of Atlantic puffin chick food; $(B, C)$ mean masses of loads $( \pm \mathrm{SD})$ fed to chicks of Atlantic puffins (B) and to common guillemots (C) at Hornøya 
Table 2. Fratercula arctica and Uria aalge. Mean daily growth rates $( \pm 1 \mathrm{SD})$ of Atlantic puffin chicks and mean mass of common guillemot chicks with wing $\geq 70 \mathrm{~mm}$ at Hornøya in 1980 to 2000. n: no. of chicks weighed and measured each year; nd: no data

\begin{tabular}{|c|c|c|c|c|c|}
\hline Year & $\begin{array}{l}\text { Atla } \\
\text { mass } \\
\left(g^{-1} d^{-1}\right)\end{array}$ & $\begin{array}{l}\text { antic puffin } \\
\text { wing length } \\
\left(\mathrm{mm} \mathrm{d}^{-1}\right)\end{array}$ & $\mathrm{n}$ & $\begin{array}{l}\text { Common gu } \\
\text { mass } \\
(\mathrm{g})\end{array}$ & $\begin{array}{c}\text { llemot } \\
\mathrm{n}\end{array}$ \\
\hline 1980 & $11.4 \pm 2.7$ & $4.1 \pm 1.5$ & 32 & $272.1-25.1$ & 82 \\
\hline 1981 & $11.2 \pm 2.3$ & $3.5 \pm 0.4$ & 28 & $268.4-30.2$ & 41 \\
\hline 1982 & $11.9 \pm 2.8$ & nd & 23 & $269.3-26.0$ & 74 \\
\hline 1983 & nd & nd & & $287.8-26.6$ & 98 \\
\hline 1988 & $9.7 \pm 4.2$ & $2.9 \pm 1.1$ & 41 & $288.9-21.9$ & 9 \\
\hline 1989 & $11.2 \pm 3.2$ & $3.9 \pm 1.2$ & 30 & $281.9-29.7$ & 61 \\
\hline 1990 & $9.8 \pm 3.3$ & $3.8 \pm 0.5$ & 24 & $307.1-29.6$ & 38 \\
\hline 1991 & $10.4 \pm 4.2$ & $3.7 \pm 0.6$ & 26 & $278.6-28.3$ & 31 \\
\hline 1992 & $13.3 \pm 3.6$ & $3.9 \pm 0.9$ & 21 & $284.9-27.2$ & 36 \\
\hline 1993 & $12.7 \pm 2.1$ & $3.1 \pm 0.6$ & 19 & $267.3-32.2$ & 17 \\
\hline 1994 & $9.1 \pm 2.0$ & $3.8 \pm 0.9$ & 10 & $290.0-25.9$ & 15 \\
\hline 1995 & $10.6 \pm 1.4$ & $3.8 \pm 0.3$ & 25 & $276.4-29.7$ & 18 \\
\hline 1996 & $12.6 \pm 2.5$ & $4.1 \pm 0.5$ & 28 & $258.3-34.5$ & 84 \\
\hline 1997 & $11.3 \pm 3.5$ & $3.6 \pm 0.8$ & 24 & $272.8-25.2$ & 89 \\
\hline 1998 & $10.5 \pm 3.8$ & $3.6 \pm 1.1$ & 31 & $265.9-29.1$ & 87 \\
\hline 1999 & $11.6 \pm 3,4$ & $3.7 \pm 0.7$ & 25 & $278.6-29.3$ & 186 \\
\hline 2000 & $12.6 \pm 2.5$ & $3.7 \pm 0.9$ & 24 & $275.8-31.5$ & 114 \\
\hline
\end{tabular}

and wing growth between 2.9 and $4.1 \mathrm{~mm} \mathrm{~d}^{-1}\left(F_{14,376}=\right.$ $4.16, \mathrm{p}=0.000$ ) (Table 2). There were however no temporal trends in growth rate, nor correlations between either of the growth indices and the proportions of any of the diet constituents or the mass or numbers of fishes in the food loads.

\section{Common guillemot}

A total of 9221 fishes weighing an estimated $98.5 \mathrm{~kg}$ were collected or observed in 17 seasons (Table 3). Most were collected over a 3 wk period or longer, and all except those in 1980 were collected in the main chick-rearing period and are therefore considered representative of the seasons sampled.

Three fish species, capelin, sandeel and herring, dominated the samples. Among the category 'other', which never constituted more than $3 \%$ of the diet, were a few gadids, wolffish and unidentified fish. The proportions of the 3 main elements varied greatly from year to year, although there was a clear dominance of capelin most years (Table 3, Fig. 4). Only in 1992, when herring made up $58 \%$ (by mass) of the chick diet, was the proportion of capelin $<50 \%$ (by mass). Herring was also important (>25\%) in 1993, 1998 and 1999. Most of the capelin, sandeels and herring were in the mean size range 100 to $150 \mathrm{~mm}$ (equivalent to I-III group capelin and herring).

Excluding data from 1980 to 1982, 1988 and 1989 due to small sample sizes and/or the fact that fishes left on the breeding ledges might not be representative of those actually eaten by the chicks, the proportion of sandeels (by mass) decreased significantly $(y=$ $31.0-0.02 x, \mathrm{r}^{2}=57.3, \mathrm{p}=0.004, \mathrm{df}=11$ ) between 1983 and 2000, while there were no temporal trends in capelin or herring content. The mean mass of each prey item varied significantly among years $\left(F_{11,9020}=\right.$ 255.0, $\mathrm{p}=0.000$, range 7.7 to $12.1 \mathrm{~g}, \mathrm{df}=11$ ) and

Table 3. Uria aalge. Protocol of sampling and percentage by numbers and by mass of prey items brought to common guillemot chicks at Hornøya, north Norway, 1980 to 2000. Data for 1980 to 1982 based on collected samples, for 1983 to 2000 mainly on items observed being carried by adult birds. n: no. of fishes; tr: trace $(<0$ to $0,5 \%)$; ?: not recorded

\begin{tabular}{|c|c|c|c|c|c|c|c|c|c|c|c|}
\hline \multirow[t]{2}{*}{ Year } & \multirow[t]{2}{*}{$\begin{array}{l}\text { Main sampling } \\
\text { dates }(\mathrm{d} / \mathrm{mo})\end{array}$} & \multirow[t]{2}{*}{$\mathrm{N}$} & \multirow[t]{2}{*}{$\begin{array}{l}\text { Total mass } \\
\qquad(\mathrm{g})\end{array}$} & \multicolumn{2}{|c|}{$\begin{array}{c}\text { Capelin } \\
\%\end{array}$} & \multicolumn{2}{|c|}{$\begin{array}{c}\text { Sandeel } \\
\%\end{array}$} & \multicolumn{2}{|c|}{$\begin{array}{c}\text { Herring } \\
\%\end{array}$} & \multicolumn{2}{|c|}{$\begin{array}{c}\text { Other } \\
\%\end{array}$} \\
\hline & & & & $\mathrm{n}$ & mass & $\mathrm{n}$ & mass & $\mathrm{n}$ & mass & $\mathrm{n}$ & mass \\
\hline 1980 & $25 / 5-30 / 6$ & 46 & 429 & 72 & 77 & 20 & 17 & 2 & 3 & 7 & 3 \\
\hline 1981 & $18-31 / 7$ & 22 & 200 & 55 & 60 & 45 & 40 & 0 & 0 & 0 & 0 \\
\hline 1982 & $?$ & 28 & 258 & 61 & 66 & 39 & 34 & 0 & 0 & 0 & 0 \\
\hline 1983 & $30 / 6-17 / 7$ & 1580 & 13394 & 59 & 73 & 41 & 27 & 0 & 0 & 0 & 0 \\
\hline 1988 & $15-20 / 7$ & 62 & 606 & 89 & 91 & 11 & 9 & 0 & 0 & 0 & 0 \\
\hline 1989 & $4-14 / 7$ & 65 & 774 & 89 & 95 & 6 & 4 & 0 & 0 & 5 & 1 \\
\hline 1990 & $12 / 6-25 / 7$ & 481 & 4857 & 44 & 53 & 45 & 34 & 11 & 13 & 0 & 0 \\
\hline 1991 & $4 / 6-25 / 7$ & 707 & 7633 & 46 & 68 & 47 & 24 & 7 & 8 & 0 & 0 \\
\hline 1992 & $14 / 6-14 / 7$ & 149 & 1566 & 23 & 22 & 26 & 19 & 51 & 58 & 0 & 0 \\
\hline 1993 & $15 / 6-28 / 7$ & 952 & 10744 & 55 & 52 & 8 & 4 & 37 & 43 & 1 & $\operatorname{tr}$ \\
\hline 1994 & $10 / 6-22 / 7$ & 529 & 4875 & 64 & 69 & 20 & 15 & 11 & 14 & 5 & 2 \\
\hline 1995 & $14 / 6-25 / 7$ & 808 & 8319 & 54 & 60 & 26 & 17 & 17 & 20 & 3 & 3 \\
\hline 1996 & $12 / 6-22 / 7$ & 756 & 8595 & 77 & 86 & 17 & 10 & 1 & 1 & 5 & 3 \\
\hline 1997 & $13 / 6-21 / 7$ & 590 & 7024 & 61 & 67 & 21 & 13 & 15 & 17 & 4 & 3 \\
\hline 1998 & $25 / 6-20 / 7$ & 870 & 10488 & 63 & 66 & 7 & 5 & 26 & 28 & 3 & 1 \\
\hline 1999 & $5-22 / 7$ & 724 & 8157 & 51 & 53 & 15 & 10 & 32 & 37 & 1 & 1 \\
\hline 2000 & $5-20 / 7$ & 894 & 10569 & 88 & 91 & 8 & 5 & 3 & 4 & 1 & 1 \\
\hline
\end{tabular}


increased between 1983 and $2000(y=$ $-548.0+0.28 x, r^{2}=70.4, p=0.001, d f=11$; Fig. 3C). Whereas there was no relationship between prey mass and the proportion (by mass) of capelin or herring in the diet, there was a strong negative relationship with that of sandeel $\left(y=0.71-0.06 x, r^{2}=81.3, p=\right.$ $0.000, \mathrm{df}=11)$. There was an inverse relationship between the yearly proportions (by mass) of capelin and herring in the diet $(y=$ $0.93-1.06 \mathrm{x}, \mathrm{r}^{2}=71.1, \mathrm{p}=0.000, \mathrm{df}=11$ ), but no significant correlations between the proportions of capelin and sandeel or herring and sandeel.

There was a large, significant variation in the mean masses of chicks with wing length of $70 \mathrm{~mm}$ or more (Table $2, F_{16,1063}=7.91, \mathrm{p}=$ $0.000)$, but no evidence of a temporal trend. Whereas chick mass was positively related to the amount of sandeels (by mass) in the diet $\left(y=262.0+107 x, \mathrm{r}^{2}=\right.$ $64.2, \mathrm{p}=0.002, \mathrm{df}=11$ ), no relationship was found with the amount of either capelin or herring. There was, however, a negative relationship between chick mass and the annual mean load mass $\left(y=336-5.6 x, r^{2}=\right.$ 47.4, $\mathrm{p}=0.013, \mathrm{df}=11$ ).

\section{Prey composition in relation to fish stocks}

There are no data on the relative abundance of the main prey fish within the normal foraging range of Atlantic puffins or common guillemots from Hornøya, but there are, with the exception of sandeels, data for the entire Barents Sea. For capelin, these are the results of autumn acoustic surveys that give direct estimates of the total stocks in the region (Anonymous 2000). The results show considerable changes over 3 orders of magnitude, with a sharp decrease in the early 1980s, a rapid increase to a peak in 1991, and a subsequent decrease again until 1994/1995 followed by another increase (Fig. 5A). Similarly indices of 0 group cod abundance stem from annual pelagic trawl surveys at the end of August and beginning of September (Anonymous 2000). Again they show large variations in stocks with minima in the early and late 1980s (Fig. 5A).

For the relative abundance of the youngest ageclasses of herring in the Barents Sea, 2 measures were chosen from survey results. One was the abundance of I-group herring as estimated using VPA-analysis (Anonymous 2000). The other was the index of 0-group herring (which move into the Barents Sea to mature) as measured in the previous year. Both these measures show very similar trends, with peaks in 1983 and 1993 (Fig. 5B).
Excluding the dietary data from 1987, 1989 and 1991 (when sample sizes were very small), there were strong $\left(r^{2}=0.27\right.$ to 0.88$)$ positive correlations between the annual proportions of capelin, herring and 0-group gadids (by mass and number) in the Atlantic puffin chick diet and the estimates or indices of abundance of the respective stocks in the Barents Sea (Table 4). All but the correlations between the proportions of herring (by number) in the diet and the herring stocks were significant.

Whereas no correlations were found between the proportion of capelin in the common guillemot chick diet and the stocks of capelin, there were again strong correlations between the proportions of herring in the diet and the 0-group survey indices and the estimates of I-group abundances (Table 4).

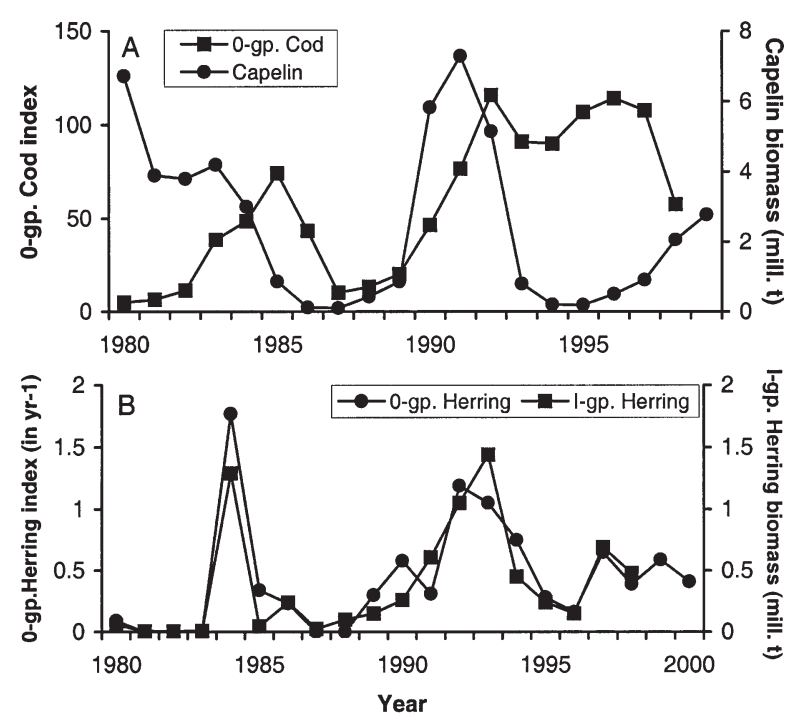

Fig. 5. (A) Estimated stock sizes of capelin and indices for 0 -group cod; (B) estimated stock sizes of I-group herring and abundance indices for 0-group herring (in the previous year) in the Barents Sea. Data from Anonymous $(2000,2001)$ 
Table 4. Fratercula arctica and Uria aalge. Correlations between annual proportions of capelin, herring and 0-group gadids in the diet of Atlantic puffin and common guillemot chicks at Hornøya and independently estimated stocks in the Barents Sea in 1980 to 2000. Stock data for total capelin and 0-group herring available up to and including 1999, those for I-group herring and 0group cod only up to 1998 (Anonymous 2000, 2001, Toresen 2000)

\begin{tabular}{|c|c|c|c|c|c|}
\hline Diet component & Stock measure & Correlation equation & $\mathrm{r}^{2}$ & $\mathrm{p}$ & $\mathrm{df}$ \\
\hline \multicolumn{6}{|l|}{ Puffin by mass } \\
\hline Capelin & Total capelin & $y=0.18+6.1 \times 10^{-5} x$ & 0.34 & 0.040 & 11 \\
\hline Herring & I-group herring & $y=-0.03+0.0028 x$ & 0.88 & 0.000 & 10 \\
\hline Herring & 0 -group herring ${ }^{a}$ & $y=-0.04+0.27 x$ & 0.66 & 0.000 & 12 \\
\hline Gadid & 0-group cod & $y=-0.06+3.0 \times 10^{-4} x$ & 0.60 & 0.003 & 10 \\
\hline \multicolumn{6}{|l|}{ Puffin by number } \\
\hline Capelin & Total capelin & $y=0.005+6.8 \times 10^{-5} x$ & 0.35 & 0.033 & 11 \\
\hline Herring & I-group herring & $y=0.005+3.2 \times 10^{-4} x$ & 0.27 & 0.09 & 10 \\
\hline Herring & 0 -group herring ${ }^{\mathrm{a}}$ & $y=0.002+0.04 x$ & 0.28 & 0.052 & 12 \\
\hline Gadid & 0-group cod & $y=-0.015+6.9 \times 10^{-4} x$ & 0.68 & 0.001 & 10 \\
\hline \multicolumn{6}{|c|}{ Guillemot by mass } \\
\hline Herring & I-group herring & $y=0.01+0.004 x$ & 0.66 & 0.004 & 9 \\
\hline Herring & 0 -group herring ${ }^{\mathrm{a}}$ & $y=-0.03+0.45 x$ & 0.68 & 0.001 & 11 \\
\hline \multicolumn{6}{|c|}{ Guillemot by number } \\
\hline Herring & I-group herring & $y=-0.009+0.003 x$ & 0.71 & 0.001 & 9 \\
\hline Herring & 0 -group herring ${ }^{a}$ & $y=-0.05+0.40 x$ & 0.71 & 0.000 & 11 \\
\hline
\end{tabular}

\section{DISCUSSION}

\section{Diet composition}

The almost total domination of fishes of high calorific value (capelin, sandeels, herring, wolffish: Montevecchi \& Piatt 1984, Barrett et al. 1987, Mårtensson et al. 1996, R.T.B. unpubl. data) in the diets of Atlantic puffin and common guillemot chicks at Hornøya corroborates other studies of auks on both sides of the Atlantic and in Alaska. In Britain, highcalorie fishes such as sandeels, herring and sprats Sprattus sprattus were often the dominant prey of both species (Bradstreet \& Brown 1985, Martin 1989, Hatchwell et al. 1992, Cook \& Hamer 1997). On the Isle of May, eastern Scotland, sandeels, sprats and herring accounted for $85 \%$ by number and $90 \%$ by mass of the Atlantic puffin chick diet, and sandeels and sprats ca. $100 \%$ of the common guillemot chick diet over 6 yr (Hislop \& Harris 1985, Harris \& Wanless 1988). In eastern Canada, capelin has a key position in all marine food webs, and comprised $80 \%$ or more of the Atlantic puffin and common guillemot chick diets in years when capelin stocks were high (Brown \& Nettleship 1984, Montevecchi 2000). Sandeels or spotted snake blenny made up an additional 5 to $15 \%$ (Birkhead \& Nettleship 1987, Nettleship 1991, Rodway \& Montevecchi 1996). In 1981, however, when capelin stocks were at a minimum (due to overfishing), immature cod made up $68 \%$ of the Atlantic puffin samples collected (Nettleship 1991). In Alaska,
Pacific sandeel Ammodytes hexapterus and capelin were the most important prey for chicks of the tufted Fratercula cirrhata and the horned puffin F. corniculata (Wehle 1983, Baird 1990).

Harris \& Hislop (1978) suggested that adult Atlantic puffins actively select against gadids (which are of lower calorific value), and thus bring back fewer than would be expected from their availability. Nettleship (1991), Russell \& Montevecchi (pers. comm.) and this study show that Atlantic puffins readily take fish of reduced calorific value and of smaller size in years when the preferred species are less available. At Hornøya, gadids were selected when both capelin and I-group herring stocks were low in the mid-1990s (Fig. 5).

Whether the adults on Hornøya selected 0-group gadids because levels of capelin and herring were low, or because those of 0-group gadids were high, is difficult to determine. This problem is exacerbated by the total lack of data concerning the local stocks of a third preferred prey, sandeels. In 1992, when stocks of both capelin and herring were relatively high (Fig. 5), gadids were also plentiful and all 3 items constituted $20 \%$ or more of the diet. In 1993, however, capelin stocks were very low while those of herring and gadids remained high, but very few gadids appeared in the food samples. Similarly, the near-dominance of the spotted snake blenny in the 1998 diet may have been due to generally low levels of the preferred prey and/or an exceptional influx of young, pelagic stages of the species into the waters around Hornøya. 
There is a suggestion, however, that sandeel availability dropped in the 1990s, as the relative harvest by common guillemots was lower than a decade earlier despite the contemporary decline in both capelin and herring stocks. Had sandeel availability remained unchanged, one would have expected a corresponding rise in the contribution of sandeels in the diet. For example, in 1989 (when capelin stocks were very low), common and Brünnich's guillemots Uria lomvia and razorbills Alca torda harvested higher proportions of capelin and fewer sandeels than in 1983 (when capelin stocks were high) (Barrett \& Furness 1990). That common guillemots were able to maintain a higher proportion of capelin than the Atlantic puffins during the 1990s may be attributed to the guillemots' ability to dive deeper and longer than puffins, which enables them to exploit schools of fishes beyond the reach of the puffins.

\section{Load masses and numbers of fishes per load}

Taking into consideration the latitudinal increase in adult body size (Barrett et al. 1985), the mean load masses of the Atlantic puffins on Hornøya in 1980 to 1982 (10.7 to $11.8 \mathrm{~g}$ ) were high. Those in 1990 to 2000 (with the exception of 1992) were, on the other hand, generally lower (5.3 to $7.7 \mathrm{~g}$ ) than those found in studies elsewhere under good conditions of food availability in Norway (10 to $16 \mathrm{~g}$ : Barrett et al. 1987), Britain (9 to $11 \mathrm{~g}$ : Cook \& Hamer 1997; 8 to $10 \mathrm{~g}$ [mean of 12 yr]: Harris 1984) or Canada (12 to $15 \mathrm{~g}$ : Nettleship 1991) and similar to the range (3 to $7.5 \mathrm{~g}$ ) recorded at Bleiksøya, North Norway, during 3 yr of food stress (Barrett \& Rikardsen 1992).

In the years when gadids were selected, load masses were low and numbers of fishes were high. This response corroborates Martin's (1989) 11 yr study at Shetland, where the mean load masses declined as feeding conditions (sandeel availability) also declined, and by Nettleship (1991), who found a much lower load mass in the year when immature gadids replaced capelin as the preferred prey. As in the present study, Nettleship found more fishes per load and Martin demonstrated a clear negative correlation between the mean load masses and the number of fishes per load as a result of non-preferred prey being smaller and lighter than preferred prey. Such small prey items are generally of poorer energetic quality than the large, preferred items (R.T.B. pers. obs.).

Atlantic puffins normally bring in 5 to 10 fishes at a time, but numbers can vary from 1 to $>60$ (Harris \& Hislop 1978). When foraging, energetic returns are expected to be greater when birds return with few, large fishes than with many, small fishes of similar, or commonly lower, energetic content. At Hornøya, Atlantic puffins were doing the former in the early 1980s and the latter a decade later. This and the progressive decrease in the amount of high-quality capelin and sandeel as the number of fishes per load increased suggests that there was a deterioration in food availability over the interceding years. This suggestion is supported by a reduction in mean load mass and an increase in both the diversity of the diet and the relative proportions of lower-quality gadids.

Paradoxically, while puffin load size decreased during the study period, that of guillemots increased at the same time as the contribution of sandeels decreased. This may again be explained by the guillemots' ability to exploit prey at deeper depths plus the larger mass:length ratio among the alternative prey, capelin and herring (Harris \& Hislop 1978, R.T.B. unpubl. data). It could, however, have been a compensatory behaviour of common guillemots which, in 2 other studies, have been found bringing larger fishes in years of poor food supply, thereby compensating for longer foraging times (Uttley et al. 1994, Montevecchi \& Myers 1996). Despite the increase, the range in load masses ( 7.7 to $12.0 \mathrm{~g}$ ) remained within that documented for common guillemots on both sides of the Atlantic (Birkhead \& Nettleship 1987, Harris \& Wanless 1988).

The possibility of a general deterioration in food availability around Hornøya is supported by an earlier observation of a decrease in diet overlap between black-legged kittiwakes, common guillemots and Atlantic puffins breeding at Hornøya, and a general decline in the number of black-legged kittiwakes breeding on the island between the 1980s and the early 1990s. Both were considered to be a response to a general decline in capelin availability (Krasnov \& Barrett 1995, Barrett \& Krasnov 1996, Anker-Nilssen et al. 1997).

\section{Chick growth}

Although there are large day-to-day variations in the mass increments of Atlantic puffin chicks (Hudson 1983), the mean maximum growth rate of normally fed chicks is ca. 11 to $13 \mathrm{~g} \mathrm{~d}^{-1}$ (Gaston 1985). At St. Kilda, Scotland, growth of Atlantic puffin chicks was retarded when food supplies dropped, and at Bleiksøy, north Norway, a period of food stress in the 1980s resulted in chick growth rates of only 2.4 to $4.1 \mathrm{~g} \mathrm{~d}^{-1}$ and a reduced chick survival in 3 seasons (Harris 1978, Barrett \& Rikardsen 1992). Wehle (1983) associated daily growth rates of tufted and horned puffin chicks at rates $\leq 1.5 \%$ of adult body mass with poor feeding conditions, and those $\geq 2.5 \%$ adult body mass with optimal feeding conditions. At Hornøya, daily growth incre- 
ments were between 9 and $13 \mathrm{~g}$ or 1.8 and $2.7 \%$ adult body mass (= $480 \mathrm{~g}$, Barrett et al. 1985), and even in 1988, when stocks of herring, capelin and 0-group cod were very low, there was no sign of reduced growth (present Table 2 and Anker-Nilssen et al. 1997). The lack of evidence of any reduction in growth in the 1990s suggests that adults were able to 'buffer' against any deterioration in food availability by (e.g.) increasing feeding rates or adjusting foraging behaviour, as demonstrated for common guillemots (Burger \& Piatt 1990, Monaghan et al. 1994).

The lack of a growth response by Atlantic puffin chicks may also be a result of chick growth being adjusted to food availability during years of poor or very variable food supply, i.e. growth rates in 1980 to 1982 were physiologically restrained during the years of an 'exceptionally rich' food supply (Furness \& Barrett 1985). Such physiological restraint has been demonstrated by Wehle (1983) and Cook \& Hamer (1997), who failed to induce more rapid growth of Atlantic puffin chicks through supplementary feeding. Harris \& Wanless (1988) also found no evidence of reduced growth of common guillemot chicks despite a ca. $50 \%$ reduction in food intake over a 5 yr period. They suggested that chicks did not utilize all the food fed in the years of high intake.

Although variable, the mass of large common guillemot chicks was high (23 to $28 \%$ of adult body mass = $1110 \mathrm{~g}$ ) in relation to other studies (Hedgren \& Linnman 1979, Furness \& Barrett 1985, Harris \& Wanless 1988). The lack of any temporal trends and the lack of any relationship between chick growth and diet composition or fish size (despite an increase in the latter during the study period) again suggests compensatory behavioural changes by adults.

That the quality and quantity of food given to Atlantic puffin chicks diminished but without any effect on chick growth again demonstrates the differential buffering effects of food availability among life-history and breeding parameters. Only when conditions drop below a certain critical threshold will adults channel effort away from their eggs or chicks through a reduction in foraging effort in order to maintain their own body condition and hence ensure their own survival (Cairns 1987, 1992, Johnsen et al. 1994, Wernham \& Bryant 1998). Not only was there no evidence of reduced chick growth, there was no evidence of a decrease in adult survival between 1991 and 1997 that might have resulted from increased foraging effort (Erikstad et al. 1998). Further, there was even a slight increase in the breeding population of Atlantic puffins between 1982 and 1993 (Anker-Nilssen et al. 1996). That the common guillemot population also increased at a rate of $13 \%$ per annum after its collapse in 1985 to 1987 (R.T.B. unpubl. data) demonstrates that while conditions may have deteriorated from what was described as 'exceptionally rich' in the early 1980s, they were still good in the 1990s.

This is probably because of the availability of at least 3 high-quality prey species (capelin, sandeels, herring) in the southern Barents Sea. This enables the adults to find alternative prey when the stock of one or the other drops below a threshold at which it is energetically viable to harvest as prey. This is in contrast to the situations off Newfoundland, Shetland or Røst, where a decline in capelin, sandeels or herring respectively and the lack of a suitable alternative prey resulted in breeding failures (Anker-Nilssen 1992, Nettleship 1991, Monaghan et al. 1994). At Newfoundland, Atlantic puffin chicks died of starvation when mature capelin was unavailable, and at Shetland, threshold conditions were reached in 1990 when adult common guillemots failed to find sufficient sandeels, resulting in a reduction in fledging success and chick mass (Uttley et al. 1994).

\section{Puffins and guillemots as bio-indicators}

Barrett \& Krasnov (1996) demonstrated a close statistical correlation between the amounts of herring in the diet of Atlantic puffins, black-legged kittiwakes and common guillemots on Hornøya and that of young herring in the Barents Sea in 1980 to 1994, but not between capelin in the diet and the measured capelin stocks. They argued that much of the distribution of the youngest stages of herring was restricted to coastal banks and central and southern parts of the Barents Sea (Loeng 1989) and thus within the foraging range of seabirds at Hornøya. This facilitated the positive correlation, whereas the large differences in spatial scaling between the normal foraging ranges of seabirds (tens of kilometres) and that of capelin surveys (hundreds of kilometres) precluded any correlation between dietary content and capelin stocks. Nor was any account made for the fact that availability does not necessarily reflect abundance. It seems, however, that the addition of 6 years' data (1995 to 2000) has improved the robustness of the statistics, and the consequent correlations between capelin in the diets of Atlantic puffins and capelin abundance and dietary gadids and 0-group cod indices show that this argument was partially incorrect. This is despite the lack of a clear hierarchy of prey preference by Atlantic puffins (Cairns 1992). Whereas there have been numerous studies showing correlations between prey choice and local prey availability, the present study is one of the few that support the idea that prey availability and abundance over large scales can be predicted at local scales (i.e. within seabird foraging ranges) (Hislop \& Harris 1985, Montevecchi \& Myers 
1995). The fact that similar correlations were not found in the common guillemot diet also supports the hypothesis that such relationships will first appear among smaller species that are less capable of finding alternative food than larger ones. It may also be partially a result of the guillemots' 'intermediate' chick-departure strategy, whereby which chick food makes up a much smaller part of the total food demand of the breeding population and over a shorter time scale than is the case for puffins (Gaston \& Jones 1998, p 116).

Hislop \& Harris (1985) found a robust correlation between the sprat and 0-group herring content of Atlantic puffin chick diet on the Isle of May, and independently measured the total biomass of sprat and the I-group herring index early the following year in the North Sea. Similarly, Montevecchi \& Myers (1995) found close associations between landings by northern gannets Morus bassanus and fisheries' catches of mackerel Scomber scombrus and short-finned squid Illex illecebrosus within Newfoundland waters. The latter possibly resulted from an interaction between the thermal preferences of the prey and variations in the water temperature that influence the migration of warm-water pelagic prey in the NW Atlantic. A similar interaction was found by Barrett \& Krasnov (1996) at Kharlov, off the Kola Peninsula in the eastern Barents Sea, where herring appeared in the diet of common guillemot chicks only in years when herring stocks were large and the distribution of the youngest cohorts spread far eastwards.

It has been argued that responses by seabirds during years of low food availability are generally easier to interpret when only 1 prey species is involved (e.g. sandeels at Shetland, Monaghan et al. 1996; capelin in Newfoundland: Nettleship 1991) than when several high-quality species are available (e.g. this study). However, when exploiting only a single prey, adults may be forced to hunt for that 1 prey in the absence of alternatives, such that the diet composition will tell us little about relative abundances until a minimum threshold is reached (Monaghan et al. 1996). When alternative prey is present, the ability to switch from one to the other will give a better indication of relative abundances. In such a situation, it was argued that Atlantic puffins were specialized feeders offering 'broadened opportunities and promising systems for use as bio-indicators of marine environmental changes' (Nettleship 1991). The present study suggests that rather than being specialists, Atlantic puffins may, in other localities, be opportunistic and harvest that which is available at a given time. Nevertheless, at Hornøya they seem to respond to the availability of at least 3 prey species and the close correlation between chick diets and independent surveys despite the adults' capacity and possibility to exploit alternative prey show that diet composition can be used as an indicator of the availability of capelin, 0-group cod and I-group herring in the southern Barents Sea. The response by common guillemots on the other hand, which have the better capacity to find alternative food, is less well suited for use as a bio-indicator of prey conditions, but still useful in monitoring the stocks of young herring.

Acknowledgements. The Norwegian Lighthouse Authority is thanked for permission to use the lighthouse on Hornøya as a base, as are the lighthouse keepers for their hospitality and logistic help and all who have otherwise helped me in the field over the years on Hornøya. I am also grateful to T. Pedersen for help in identifying prey items, the Otago Museum, Dunedin, New Zealand, for providing facilities during the final stages of the preparation of the manuscript, and to W. A. Montevecchi for his helpful comments on an early draft. The Norwegian Research Council, the Norwegian Directorate for Nature Management, Tromsø University Museum and the University of Tromsø financed this study.

\section{LITERATURE CITED}

Anker-Nilssen T (1987) The breeding performance of puffins Fractercula arctica on Røst, northern Norway in 19791985. Fauna Norv Ser C Cinclus 10:21-38

Anker-Nilssen T (1992) Food supply as a determinant of reproduction and population development in Norwegian puffins Fratercula arctica. PhD thesis, University of Trondheim

Anker-Nilssen T, Brøseth H (1998) Hekkebiologiske langtidsstudier av lunder på Røst en oppdatering med resultater fra 1995-1997. NINA Fagrapp 32:1-46 (in Norwegian)

Anker-Nilssen T, Tatarinkova Y (2000) The Atlantic puffin Fratercula arctica In: Anker-Nilssen T, Bakken V, Strøm H, Golovkin AN, Bianki VV, Tatarinkova IP (eds) The status of marine birds breeding in the Barents Sea region. Nor Polarinst Rapp 13:137-143

Anker-Nilssen T, Erikstad KE, Lorentsen SH (1996) Aims and effort in seabird monitoring: an assessment based on Norwegian data. Wildl Biol 2:17-26

Anker-Nilssen T, Barrett RT, Krasnov JV (1997) Long- and short-term responses of seabirds in the Norwegian and Barents Seas to changes in stocks of prey fish. Alsk Sea Grant Program AK-SG-97-01:683-698

Anker-Nilssen T, Bakken V, Strøm H, Golovkin AN, Bianki VV, Tatarinkova IP (2000) (eds) The status of marine birds breeding in the Barents Sea region. Nor Polarinst Rapp 13:137-143

Anonymous (2000) Report of the Northern pelagic and blue whiting fisheries working group. Int Counc Explor Sea Comm Meet 2000/ACFM:16:1-278

Anonymous (2001) Report of the arctic fisheries working group. Int Counc Explor Sea, Copenhagen Comm Meet 2001/ACFM:02:1-380

Baird PH (1990) Influence of abiotic factors and prey distribution on diet and reproductive success of three seabird species in Alaska. Ornis Scand 21:224-235

Barrett RT (1984) Comparative notes on eggs, chick growth and fledging of the Razorbill Alca torda in north Norway. Seabird 7:55-61

Barrett RT (1991) Shags (Phalacrocorax aristotelis) as poten- 
tial samplers of juvenile saithe (Pollachius virens [L]) stocks in northern Norway. Sarsia 76:153-156

Barrett RT (1996) Prey harvest, chick growth, and production of three seabird species on Bleiksøy, north Norway during years of variable food availability. Can Wildl Serv Occ Pap 91:120-26

Barrett RT (2001) The breeding demography and egg size of north Norwegian Atlantic puffins Fratercula arctica and Razorbills Alca torda during 20 yr of climatic variability. Atl Seabirds 3:97-112

Barrett RT, Furness RW (1990) The prey and diving depths of seabirds on Hornøy, North Norway after a decrease in the Barents Sea capelin stocks. Ornis Scand 21:179-186

Barrett RT, Golovkin AN (2000) Common guillemot Uria aalge. In: Anker-Nilssen T, Bakken V, Strøm H, Golovkin AN, Bianki VV, Tatarinkova IP (eds) The status of marine birds breeding in the Barents Sea region. Nor Polarinst Rapp 13:114-118

Barrett RT, Krasnov YV (1996) Recent responses to changes in stocks of prey species by seabirds breeding in the southern Barents Sea. ICES J Mar Sci 53:713-722

Barrett RT, Rikardsen F (1992) Chick growth, fledging periods and adult mass loss of Atlantic puffins Fractercula arctica during years of prolonged food shortage. Colon Waterbirds 15:24-32

Barrett RT, Fieler R, Anker-Nilssen T, Rikardsen F (1985) Measurements and weight changes of Norwegian adult puffins Fractercula arctica and kittiwakes Rissa tridactyla during the breeding season. Ringing Migr 6:102-112

Barrett RT, Anker-Nilssen T, Rikardsen F, Valde K, Røv N, Vader W (1987) The food, growth and fledging success of Norwegian puffin chicks Fractercula arctica in 19801983. Ornis Scand 18:73-83

Barrett RT, Asheim M, Bakken V (1997a) Ecological relationships between two sympatric congeneric species, common murres and thick-billed murres, Uria aalge and U. lomvia, breeding in the Barents Sea. Can J Zool 75:618-631

Barrett RT, Bakken V, Krasnov YV (1997b) The diets of common and Brünnich's guillemots Uria aalge and Uria lomvia in the Barents Sea region. Polar Res 16:73-84

Birkhead TR, Nettleship DN (1987) Ecological relationships between common murre, Uria aalge, and thick-billed murre, Uria lomvia, at Gannet Islands, Labrador. III. Feeding ecology of the young. Can J Zool 65:1638-1649

Bradstreet MSW, Brown RGB (1985) Feeding ecology of the Atlantic Alcidae. In: Nettleship DN, Birkhead TR (eds) The Atlantic Alcidae. Academic Press, London, p 263-318

Brown RGB, Nettleship DN (1984) Capelin and seabirds in the northeast Atlantic. In: Nettleship DN, Sanger GA, Springer PF (eds) Marine birds: their feeding ecology and commercial fisheries relationships. Can Wildl Serv Spec Publ, Ottawa, p 184-194

Brun E (1979) Present status and trends in population of seabirds in Norway. US Fish Wildl Serv Res Rep 11: 289-301

Burger AE, Piatt JF (1990) Flexible time budgets in breeding common murres: buffers against variable prey abundance. Stud Avian Biol 14:71-83

Burger AE, Simpson M (1986) Diving depths of Atlantic puffins and common murres. Auk 103:828-831

Cairns DK (1987) Seabirds as indicators of marine food supplies. Biol Oceanogr 5:261-271

Cairns DK (1992) Bridging the gap between ornithology and fisheries biology: use of seabird data in stock assessment models. Condor 94:811-824

Cook MI, Hamer KC (1997) Effects of supplementary feeding on provisioning and growth rates of nestling Puffins Frac- tercula arctica: evidence for regulation of growth. J Avian Biol 28:56-62

Erikstad KE, Anker-Nilssen T, Barrett RT, Tverraa T (1998) Demografi og voksenoverlevelse i noen norske sjøfuglbestander. NINA Oppdragsmeld 515:1-15

Furness RW, Barrett RT (1985) The food requirements and ecological relationships of a seabird community in north Norway. Ornis Scand 16:305-313

Gaston AJ (1985) Development of the young in the Atlantic Alcidae. In: Nettleship DN, Birkhead TR (eds) The Atlantic Alcidae. Academic Press, London, p 319-354

Gaston AJ, Jones IL (1998) Bird families of the world: the Auks Alcidae. Oxford University Press, Oxford

Harris MP (1978) Supplementary feeding of young puffins Fratercula arctica. J Anim Ecol 47:15-23

Harris MP (1980) Breeding performance of puffins Fratercula arctica in relation to nest density, laying date and year. Ibis 122:193-209

Harris MP (1984) The puffin. Poyser, Calton

Harris MP, Hislop JRG (1978) The food of young Puffins Fractercula arctica. J Zool (Lond) 185:213-236

Harris MP, Wanless S (1988) The breeding biology of guillemots Uria aalge on the Isle of May over a six-year period. Ibis 130:172-192

Hatchwell BJ, Birkhead TR, Goodburn SF, Perrins JM, Jones SE (1992) Chick diets and food intake of nestling common guillemots Uria aalge: an inter-colony comparison. Seabird 14:15-20

Haug T, Krøyer AB, Nilssen KT, Ugland KI, Aspholm PE (1991) Harp seals Phoca groendlandica invasions in Norwegian coastal waters: age composition and feeding habits. ICES J Mar Sci 48:363-371

Hedgren S, Linnman $\AA$ (1979) Growth of guillemot Uria aalge chicks in relation to time of hatching. Ornis Scand 10: 29-36

Hislop JRG, Harris MP (1985) Recent changes in the food of young puffins Fractercula arctica on the Isle of May in relation to fish stocks. Ibis 127:234-239

Hudson PJ (1983) The variation and synchronization of daily weight increments of Puffin chicks Fractercula arctica. Ibis 125:557-561

Johnsen I, Erikstad KE, Sæther BE (1994) Regulation of parental investment in a long-lived seabird, the puffin Fratercula arctica: an experiment. Oikos 71:273-278

Krasnov JV, Barrett RT (1995) Large-scale interactions among seabirds, their prey and humans in the southern Barents Sea. In: Skoldal HR, Hopkins C, Erikstad KE, Leinaas HP (eds) Ecology of fjords and coastal waters. Elsevier, Amsterdam, p 443-456

Loeng H (1989) Ecological features of the Barents Sea. In: Rey L, Alexander V (eds) Proceedings of the Sixth Conf Comite Arctique International. Brill Academic Publishers, Leiden, p $327-365$

Mårtensson PE, Gotaas ARL, Nordøy ES, Blix AS (1996) Seasonal changes in energy density of prey of northeast Atlantic seals and whales. Mar Mamm Sci 12:635-640

Martin AR (1989) The diet of Atlantic puffin Fratercula arctica and northern gannet Sula bassana chicks at a Shetland colony during a period of changing prey availability. Bird Study 36:170-180

Monaghan P, Walton P, Wanless S, Uttley JD, Burns MD (1994) Effects of prey abundance on the foraging behaviour, diving efficiency and time allocation of breeding guillemots Uria aalge. Ibis 136:214-222

Monaghan P, Wright PJ, Bailey MC, Uttley JD, Walton P, Burns MD (1996) The influence of changes in food abundance on diving and surface-feeding seabirds. Can Wildl 
Serv Occ Pap 91:10-19

Montevecchi WA (1993) Birds as indicators of change in marine prey stocks. In: Furness RW, Greenwood JJD (eds) Birds as monitors of environmental change. Chapman \& Hall, London, p 217-266

Montevecchi WA (2000) Seabirds. In: Bundy A, Lilly G, Sheldon P (eds) A bulk-biomass model of the Newfoundland and Labrador Shelves. Can Tech Rep Fish Aquat Sci 2310:15-18

Montevecchi WA, Myers RA (1995) Prey harvests of seabirds reflect pelagic fish and squid abundance on multiple spatial and temporal scales. Mar Ecol Prog Ser $117: 1-9$

Montevecchi WA, Myers RA (1996) Dietary changes of seabirds indicate shifts in pelagic food webs. Sarsia 80: 313-322

Montevecchi WA, Piatt J (1984) Composition and energy contents of mature spawning capelin (Mallotus villosus): implications for seabird predators. Comp Biochem Physiol A 78:15-20

Montevecchi WA, Birt VL, Cairns DK (1988) Dietary change of seabirds associated with local fisheries failures. Biol Oceanogr 5:153-161

Nettleship D N (1991) The diet of Atlantic puffin chicks in Newfoundland before and after the initiation of an international capelin fishery, 1967-84. In: Bell BD (ed) Proc 20th Int Ornitholog Congress. New Zealand Ornitholog Congress Board, Wellington, p 2263-2271

Piatt JF, Nettleship DN (1985) Diving depths of four alcids. Auk 102:293-297

Editorial responsibility: Otto Kinne (Editor),

Oldendorf/Luhe, Germany
Rodway MS, Montevecchi WA (1996) Sampling methods for assessing the diets of Atlantic puffin chicks. Mar Ecol Prog Ser 133:41-55

Rodway MS, Chardine JW, Montevecchi WA (1998) Intracolony variation in breeding performance of Atlantic puffins. Colon Waterbirds 21:171-184

Sakshaug E (1997) Biomass and productivity distributions and their variability in the Barents Sea. ICES J Mar Sci 54: 341-350

Sakshaug E, Bjørge A, Gulliksen B, Loeng H, Mehlum F (1994) Structure, biomass distribution, and energetics of the pelagic ecosystem in the Barents Sea: a synopsis. Polar Biol 14:405-411

Strann KB, Vader W, Barrett RT (1991) Auk mortality in fishing nets in north Norway. Seabird 13:22-29

Toresen (ed) (2000) Havets ressurser. Fisken Havet Særnr 1: $1-156$

Uttley JD, Walton P, Monaghan P, Austin G (1994) The effects of food abundance on breeding performance and adult time budgets of guillemots Uria aalge. Ibis 136:205-213

Vader W, Barrett RT, Erikstad KE, Strann KB (1990) Differential responses of common and thick-billed murres to a crash in the capelin stock in the southern Barents Sea. Stud Avian Biol 14:175-180

Wehle DHS (1983) The food, feeding, and development of young tufted and horned puffins in Alaska. Condor 85: $427-442$

Wernham CV, Bryant DM (1998) An experimental study of reduced parental effort and future reproductive success in the puffin Fratercula arctica. J Anim Ecol 67:25-40

Submitted: July 18, 2001; Accepted: October 30, 2001

Proofs received from author(s): March 18, 2002 